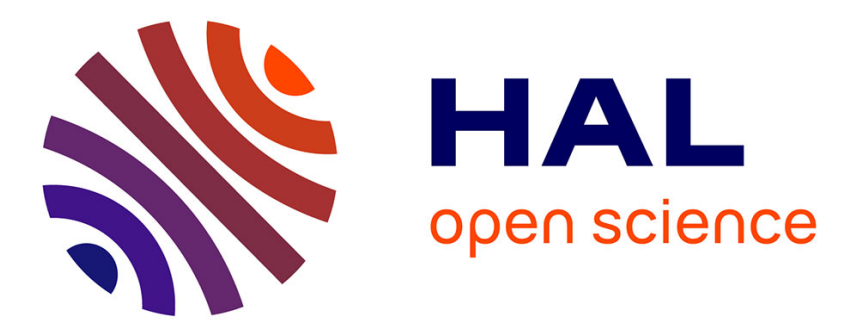

\title{
Robert Holcot's De imputabilitate peccati Is Actually Osbert of Pickenham's Utrum omne peccatum sit imputabile voluntati
}

Christopher Schabel, Callan Ledsham

\section{- To cite this version:}

Christopher Schabel, Callan Ledsham. Robert Holcot's De imputabilitate peccati Is Actually Osbert of Pickenham's Utrum omne peccatum sit imputabile voluntati. Bulletin de Philosophie Médiévale, 2020. hal-03175629

\author{
HAL Id: hal-03175629 \\ https://hal.science/hal-03175629
}

Submitted on 20 Mar 2021

HAL is a multi-disciplinary open access archive for the deposit and dissemination of scientific research documents, whether they are published or not. The documents may come from teaching and research institutions in France or abroad, or from public or private research centers.
L'archive ouverte pluridisciplinaire HAL, est destinée au dépôt et à la diffusion de documents scientifiques de niveau recherche, publiés ou non, émanant des établissements d'enseignement et de recherche français ou étrangers, des laboratoires publics ou privés. 


\section{ROBERT HOLCOT'S DE IMPUTABILITATE PECCATI IS ACTUALLY OSBERT OF \\ PICKENHAM'S UTRUM OMNE PECCATUM SIT IMPUTABILE VOLUNTATI \\ ERC-DEBATE-771589}

In the unfoliated editio princeps of the Dominican Robert Holcot's questions on the Sentences printed in Lyon in 1497 (reprinted there in 1505, 1510, and 1518), immediately after the Sentences questions there is a text labelled "De imputabilitate peccati," followed by fifteen "Determinationes." While there are around fifty medieval witnesses to all or part of the Sentences questions, ${ }^{1}$ the Determinationes have been identified in at most two independent Holcot manuscripts, ${ }^{2}$ Determinationes II-VII and XIII being in both Cambridge, Pembroke College 236, and Oxford, Balliol College 246, Determinationes VIII$\mathrm{XI}$ and XV in Pembroke alone. As far as we know, Determinationes XII and XIV are found nowhere else but the Lyon editions, which makes their attribution to Holcot insecure, especially considering that Determinatio I is in fact part of the first Sentences question of Holcot's junior contemporary at Oxford, the Franciscan Roger Roseth. ${ }^{3}$ It turns out that the question immediately preceding Determinatio I, the De imputabilitate peccati, is not by Holcot either, but rather belongs to the Carmelite Osbert Pickenham, being in the same relative place in all nine manuscripts of Osbert's Oxford Sentences lectures (usually as question 6): "Utrum omne peccatum sit imputabile voluntati." 4

Aside from blank pages, preliminary matter, and tabulae, the 1497 edition contains just 371 pages, and Roseth's question takes up 25 pages, so the further 'loss' of 44 pages with the De imputabilitate peccati reduces the incunabulum to just 302 pages of Holcot. The man responsible for the editio princeps, the great Jodocus Badius Ascensius, no doubt found a manuscript in which "Utrum omne peccatum sit imputabile voluntati" immediately followed the Sentences questions, and in 1953 Eligius Buytaert noted such a situation in Paris, Bibliothèque mazarine 906, where the manuscript concludes by adding this question on ff. 116va-140rb, as Pascale Bermon has recently confirmed. ${ }^{5}$

Numerically, the weight of the evidence sides with Pickenham's nine manuscripts, rather than the Lyon edition and Mazarine codex of Holcot.

\footnotetext{
${ }^{1}$ K. H. TACHAU, "Introduction", in Robertus Holcot, Seeing the Future Clearly: Questions on Future Contingents, ed. EAdEM and P._A. STREVELER, with W._J. COURTENAY and H._G. Gelber (Studies and Texts 119), Toronto 1995, 36-38.

2 Besides Düsseldorf, Universitäts-und Landesbibliothek F.5, which is a copy of the 1505 printing. See Appendix B in J._T. SLOTEMAKER and J._C. WITT, Robert Holcot, Oxford 2016, 267-274.

${ }^{3}$ K. MICHALSKI, La philosophie au XIV siècle. Six études, ed. K. FLASCH, Frankfurt 1969 (collected studies from 1922-1937), 74 and 220 (assigning it to Roger Swineshead); O. HALlAMAA, "On the Limits of the Genre: Roger Roseth as a Reader of the Sentences", in Mediaeval Commentaries on the Sentences of Peter Lombard, vol. 2, ed. P._W. ROSEMANN, Leiden 2010, 369-404, at 370, n. 6.

${ }^{4}$ See the updated question and manuscript list in R. COPSEY, Biographical Register of Carmelites in England and Wales 1240-1540, Faversham 2020, 271. On Osbert, see B. M. XIBERTA, De scriptoribus scholasticis saeculi XIV ex ordine Carmelitarum (Revue d'histoire ecclésiastique, Bibliothèque, 6), Leuven 1931, 241-284.

5 E. BuYtAeRT, "Damascenus Latinus: on Item 417 of Stegmueller's Repertorium Commentariorum", in Franciscan Studies 13.2-3 (1953), 37-70, at 52; P. FARAGoBERMON, "Les manuscrits conservés à Paris des Quaestiones super libros Sententiarum de Robert Holkot", in Przeglqd Tomistyczny 19 (2013), 143-176, at 168.
} 
Moreover, the constant references to the Master of the Sentences indicate that the text belongs to a set of questions on that book. Crucially, where the Lyons edition reads: "Sed contra istam viam arguit quidam magister reverendus multipliciter...," half of Pickenham's manuscripts have marginal references to a name like "Tervor," e.g., Reims, Bibliothèque municipale 494, f. 45rb: "Contra positionem istam arguit m. Tervor," and f. 46va: "Tervor," and Xiberta even noted one specifying "positio magistri lohannis Trevo." The only known Oxford theologian with a name close to that is John de Trevaur, who was bachelor of theology a decade after Holcot. ${ }^{6}$

Luckily, while the question is attributed to Holcot in the standard works on Holcot, on questions on the Sentences, and on Dominican writings, ${ }^{7}$ the De imputabilitate peccati has only rarely figured in discussions of Holcot's doctrine, ${ }^{8}$ although we have only seen one vague denial of the attribution. ${ }^{9}$

With the nine Osbert of Pickenham codices, the Lyon edition, and the Mazarine copy, we now have eleven witnesses to a Carmelite text that takes up 88 columns in the 1497 print. Unfortunately, dating Pickenham's Sentences lectures is a confusing business, with opinions ranging from before 1344 to around $1360 .{ }^{10}$ In 1987 William J. Courtenay settled on the early 1350s, having formerly argued for the late 1340 s. ${ }^{11}$ The following year Katherine H. Tachau noted that a copy of Pickenham's Sentences questions was bequeathed to the Carmelite convent in Florence by Tomaso Neri, who died in 1348, implying

${ }^{6}$ W. J. COURTENAY, Schools and Scholars in Fourteenth-Century England, Princeton 1987, 335 n. 18 and 338 n. 30; XIBERTA, De scriptoribus, 252.

7 H. G. Gelber and J._T. SlOtemaker, "Robert Holkot", in The Stanford Encyclopedia of Philosophy, ed. E._N. ZALTA (Spring 2017 Edition); SLOTEMAKER and WITT, Robert Holcot, 2; J. T. Slotemaker, "Robert Holcot", in Encyclopedia of Medieval Philosophy, ed. H. LAGERLUND, 2 vols., Dordrecht 2011, vol. 2, 1145a-1148b; H._G. GELBER, It Could Have Been Otherwise: Contingency and Necessity in Dominican Theology at Oxford, 13001350, Leiden 2004, 95; F. HofFMANN, Die theologische Methode des Oxforder Dominikanerlehrers Robert Holcot, Münster 1972, 399 and 401; F. STEGMÜLLER, Repertorium Commentariorum in Sententias Petri Lombardi, vol. I, Würzburg 1947, 363 no. 740; T. KAEPPELI, Scriptores Ordinis Praedicatorum Medii Aevi, vol. III, I-S, Roma 1980, 318 no. 3499.

${ }^{8}$ Some examples: C. Grellard, “Que m'est-il permis d'ignorer? La foi, l'ignorance et les limites acceptables de l'hétérodoxie", in Genèses antiques et médiévales de la foi, ed. C. Grellard, P. Hoffmann, and L. Lavaud, Paris 2020, 429-449; J. Marenbon, Pagans and Philosophers: The Problem of Paganism from Augustine to Leibniz, Princeton 2015, 183 (and n. 90); J. W. J. LAEMERS, Invincible Ignorance and the Discovery of the Americas: The History of an Idea from Scotus to Suárez, PhD dissertation, lowa 2011, 132 n. 79 and 315 n. 53; N. L. TURNer, "Robert Holcot on the Jews", in Chaucer and the Jews: Sources, Contexts, Meanings, ed. S._M. DeLANY, New York 2002, 133-144, at 143 (and n. 13); J. M. INCANDELA, "Robert Holcot, O.P., on Prophecy, the Contingency of Revelation, and the Freedom of God", in Medieval Philosophy and Theology 4 (1994), 165-188, at 186 (and n. 56); MICHALSKI, La philosophie au XIV siècle, 216.

${ }^{9}$ D. P. BAKER, Literature, Logic and Mathematics in the Fourteenth Century, PhD thesis, University of Durham 2013, 86 n. 191, speaking of one of the early prints and probably referring to the Roseth question: "[T]his volume also contains a treatise De imputabilitate peccati, and another 'questio', neither by Holcot, although the first is ascribed to him."

${ }^{10}$ XIBERTA, De scriptoribus, 242 supports 1344 or before, while L._A. KenNEDY, "Osbert of Pickenham, O. Carm. (fl. 1360) on the absolute power of God", in Carmelus 35 (1988), 178-225, tends to the other end.

${ }^{11}$ Courtenay, Schools and Scholars, 338-339 n. 30; cf. IDEM, Adam Wodeham. An Introduction to His Life and Writings (Studies in Medieval and Reformation Thought 21), Leiden 1978, 122 
that the text must have been written considerably earlier, which would explain why Osbert refers to Thomas Bradwardine as chancellor of London rather than archbishop of Canterbury. ${ }^{12}$ In Pickenham's question 9, which is one of his introitus questions on the Sentences, he refers three times to a "reverendus magister meus" who "replicat" against him, identified in the margins as "Heckelbri," "Heychilliari," or "Hetherbri," the famous secular master of arts William Heytesbury, suggesting a relationship between socii. Heytesbury was doctor of theology by July 1348 , so his Sentences lectures took place before that. ${ }^{13}$ In his introitus to his Bible lectures, the Carmelite Geoffrey Alienand seems to describe the debate between Heytesbury and Osbert, and Geoffrey was called inceptor in February $1350 .{ }^{14}$ Finally, the reference to Trevaur even gives the impression that he and Pickenham were socii lecturing together on the Sentences; Trevaur was bachelor of theology by 7 July 1343, making 1342-1343 the latest possible year for his reading the Sentences, which would account for Pickenham's lack of citations of Bradwardine's De causa Dei. ${ }^{15}$

The only pressing difficulty is that Osbert also cited Nicholas of Aston, a secular who did not incept as doctor of theology until 1358 and, as Joel Bender remarks, in the records for Queen's College, where Aston resided from at least 1350, "he is never referred to as a Bachelor of Theology," even when he obviously was one: "The documents either call him a Master (in the case of the earlier documents a reference to his Arts degree), or just by name." Nevertheless, this is precisely what bachelors of theology often did with their secular socii, whom they called magistri even though they were also bachelors of theology. Indeed, regarding a key document from July 1350, Bender himself relates that "it seems inconceivable that Aston would not have read the Sentences at a time when he was referred to as a senior fellow."16

Further research and editing is required on the works of Oxford theologians from the late 1330 s to early 1350 s to determine whether De imputabilitate peccati is from the early 1340s, as is likely, or the early 1350s, but at least we now know it is not from the early 1330s.

Chris SCHABEL

Callan LEDSHAM

\footnotetext{
${ }^{12}$ K._H. TACHAU, Vision and Certitude in the Age of Ockham. Optics, Epistemology and the Foundations of Semantics 1250-1345 (Studien und Texte zur Geistesgeschichte des Mittelalters 22) Leiden 1988, 311 n. 122, citing K._W. HUMPHREYS, The Library of the Carmelites of Florence at the End of the Fourteenth Century, Amsterdam 1964, 27; XIBERTA, De scriptoribus, 242.

${ }^{13}$ A._M. EMDEN, A Biographical Register of the University of Oxford to A.D. 1500, vol. II: $\mathrm{F}$ to O, Oxford 1958, 927b. An edition of the question is in progress.

${ }^{14}$ COPSEY, Biographical Register, 38b. An edition of the question is in progress.

${ }^{15}$ A._M. EMDEN, A Biographical Register of the University of Oxford to A.D. 1500, vol. III: P to Z, Oxford 1969, 1898a; XIBERTA, De scriptoribus, 242.

${ }^{16}$ J.L. BENDER, Nicholas Aston: A Study in Oxford Thought after the Black Death, PhD dissertation, University of Wisconsin-Madison 1979, pp. 5-7. COURTENAY, Schools and Scholars, 339 n. 30 and 334-335 n. 17, argued for a date after 1350 in rejecting the hypothesis in Z. KALUZA, "L'œuvre théologique de Nicolas Aston", in Archives d'histoire doctrinale et littéraire du Moyen Âge 45 (1978), 45-82, that Aston lectured before 1348 (supposing 1345), a hypothesis repeated in the reprint in Z. KALUZA, Études doctinales sur le XIV siècle. Théologie, Logique, Philosophie (Études de Philosophie Médiévale 101), Paris 2013, 55.
} 
